\title{
飛騨国の番所普請に関する木取仕様帳について 江戸時代における建築寿命の一実態 \\ AN ANALYSIS OF THE OLD DOCUMENTS ABOUT REGULATION OF CUTTING TREES IN THE CASE OF BUILDING ACTIVITIES IN HIDA
}

A statistical case study of the life span of wooden buildings in the Edo period

\section{中 村 㻟 巳*}

\section{Takumi NAKAMURA}

This report will discuss about the old construction documents about guard stations in the Edo period. I point out the characteristics of the documents from the viewpoint of regulation of cutting trees, promotion of recycle of used members, and management of the life span of buildings. I calculate the life span and the amount of wooden consumption of the buildings by analyzing the figure recorded on the documents. The figure is between 24 and 80 years, and the average is about 54 years.

Keywords : Old Documents in Hida, Life Span of Wooden Buildings, the Amount of Wooden Consumption, Regulation of Cutting Trees 飛騨郡代高山陣屋文書，建築寿命，木材量，伐木規制

\section{はじめに}

江戸時代に対する視点として、環境保全の仕組みを積極的に評価 する論考は多くみられる注1)。その評価軸のひとつに、森林資源の枯 渴という環境問題を抱えながら豊かな森林を保持し続けた、という ものが挙げられる。例えばコンラッド・タットマンは、土木建築用 材などで大量の木材を消費しながらなぜ森林が維持されたのかを、 生物的要因、技術、倫理観、制度、生活様式にわたり概説する注2)。 そのなかで、各地の藩領における平面規模に関わる建築規制を取り 上げて、森林資源の限界性に直面した領主による資源保全のための 対応策と位置づける注3)。江戸時代を「緑の列島」と評価できるのか、 環境保全という現代的価值観に捉われて、染意的な判断は避ける心゙ きである。まずは評価の前に、「尽山」（森林資源の枯渇）という環 境問題の萌芽に直面していた時代における、建築用材供給や建築規 制の具体的なあり方を明らかとする積み重齐が求められる。特に、 大量の木造建築群を保有し、長期継続的な造営・維持管理を担って いた主体においては、森林資源の保全ないし有効利用に関わる組織 的な試みが予想される注4)

飛騨郡代高山陣屋文書注5) には、民家注6)、寺社、郷蔵、陣屋、番 所、橋などの伐木 ・ 用材供給 - 工事史料が伝存し、幕府直轄領・飛 騨国における森林資源と建築行為の関係を追究できる貴重な情報源 となっている。普請文書の書式は建築類型ごとに異なるが、本稿で は番所普請に関わる史料を取り上げる。その分析を通して、建築規 制の具体的なあり方をみていく注7)。さらに、史料に登場する建築寿
命や使用木材量の記述に着目し、その数值的状況を提示する。江戸 時代の建築寿命に関わる詳細かつまとまった史料の存在は希少であ り、数的分析に值すると考えるためである。なお、本稿では建築物 が建設（建替ないし類焼後の再建）されてから辿る年数を「建築年 齢」とし、建設ないし建替から次の建替までに要した年数を「建築 寿命」と表記する。

建築寿命を算出する分析手法を提示した日本建築史研究として、 関野克 (家屋年齢構成の研究) 注8)、伊藤ていじ (中世の民家) 注9)、 伊原惠司（重要文化財の寺社） 注10）、草野和夫（近世の民家）注11） 宮澤智士（棟札を持つ民家）注12）、生野勇（同）注13）、平山育男（現 存の移築民家）注 14)の研究がみられる。建築寿命を把握する分析手 法には、更新頻度（地区内の一定期間における建替率）などから統 計的に推定する方法と、実際に解体された時点の建築年齢（実態と しての建設から解体までの期間）を収集する方法がある注15）。後者 の方法が実態に即した検討といえるが、前者の方法には統計の抽出 が容易であるという利点がある。寿命の歴史的実態に関する具体的 な情報が乏しい現在、筆者は後者の方法による事例の集積が重要と 考えている。本稿でも具体的な建物に関する寿命の数值的情報に着 目する。また、建物の木材量を史料から検討する研究は、建築史の みならず林業史でも行われる手法である注16)。しかしいずれも本稿 で示すようなライフサイクルの把握がないため（既往研究は建設時 点のみに着目する)、提示された数值と実態との関係に乘離があるこ とも指摘しておきたい注17)。

本論文は，拙稿「飛騨国の番所普請にみる木造建築のライフサイクルと森林資源の保全(その 1) - 木取仕様帳にみる環境保全の様相について」(日本建築学会関東支部研究報告 集 II，2008。同「審查付き研究報告集』に再録）「「同(その 2)一「建替」「修復「「屋根葺替」に至る建築年齢と木材量からみた寿命の実態」(同)を再構成したものである。

日本学術振興会 特別研究員・博士(工学) Research Fellow of the Japan Society for the Promotion of Science, Dr. Eng. 


\section{1. 番所の概要}

幕領となった元禄 5 年（1692）において飛騨国あわせて 31 ケ所 の口留番所が設置されていた注18)。寛政 2 年（1790）には往来の少 ない 14 ヶ所が閉鎖され、17 ケ所となっている。その主要な役割は、 出入りの旅客と荷物を検查し、物資に対しては運上金を課すもので あった。番所の空間構成は、「石垣」「柵」に囲われた敷地に「木戸 門」が設けられ、敷地内の中心に番所(「番屋」と記載される場合も ある）が立つことが共通してみられる。番所は地域によって「板葺」 と「萱莫」の場合がある。絵図にみられる平面は (図 1 ) 、囲炉裏や 「戸棚」のある「居間」、「押入」が設けられた「御用場」ささらに「物 置」「寝間」「水流」「路次」「縁」などからなる。飛騨国における各 地域の農家に類似する建築であることが指摘できる。

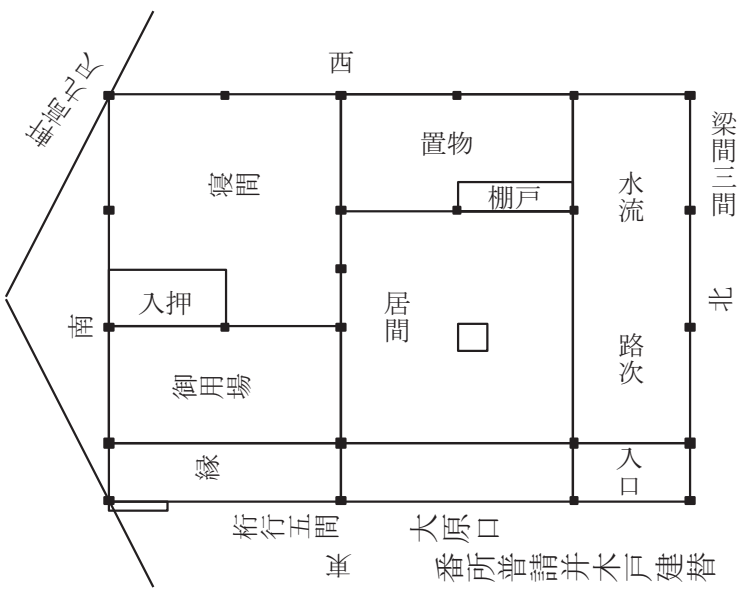

図 1 大原口番所

（岐阜県歴史資料館所蔵の絵図より作成）注19）

\section{2. 木取仕様帳の内容}

\section{1) 史料の概要}

「飛騨郡代高山陣屋文書」(岐阜県歴史資料館所蔵）には口留番所 の普請に関する 95 点の史料が残されている。残存年代は宝暦 4 年 （1754）から文久元年（1861）である。その内容は目論見帳、出来 形帳、絵図に大別できる。しかし全ての建築工事に目論見帳と出来 形帳が揃って残存することは少ない。両者の残存のほか、「目論見帳 の夕」「目論見帳に朱書で出来形帳を追筆」「出来形帳のみ」という 場合がある。これらは、高山陣屋から幕府勘定所一宛てられた史料 の控えである。本稿では目論見帳と出来形帳のことを、その記載内 容から木取仕様帳と呼ぶ。これは飛騨郡代高山陣屋文書に残る建築 史料で度々記載される用語である。

後述するように、本稿で検討する木取仕様帳の重要な特徵は、過 去における建築工事の履歴を明記する点である。よって、一点の木 取仕様帳から、過去の建築工事も追跡できることが本研究を可能と する。表 1 は 17 ケ所の番所について、木取仕様帳から建築工事の 履歴をまとめたものである。以下で木取仕様帳を例示し、その記載 内容の特徴を述べていこう。
表 1 飛騨国における番所普請の履歴

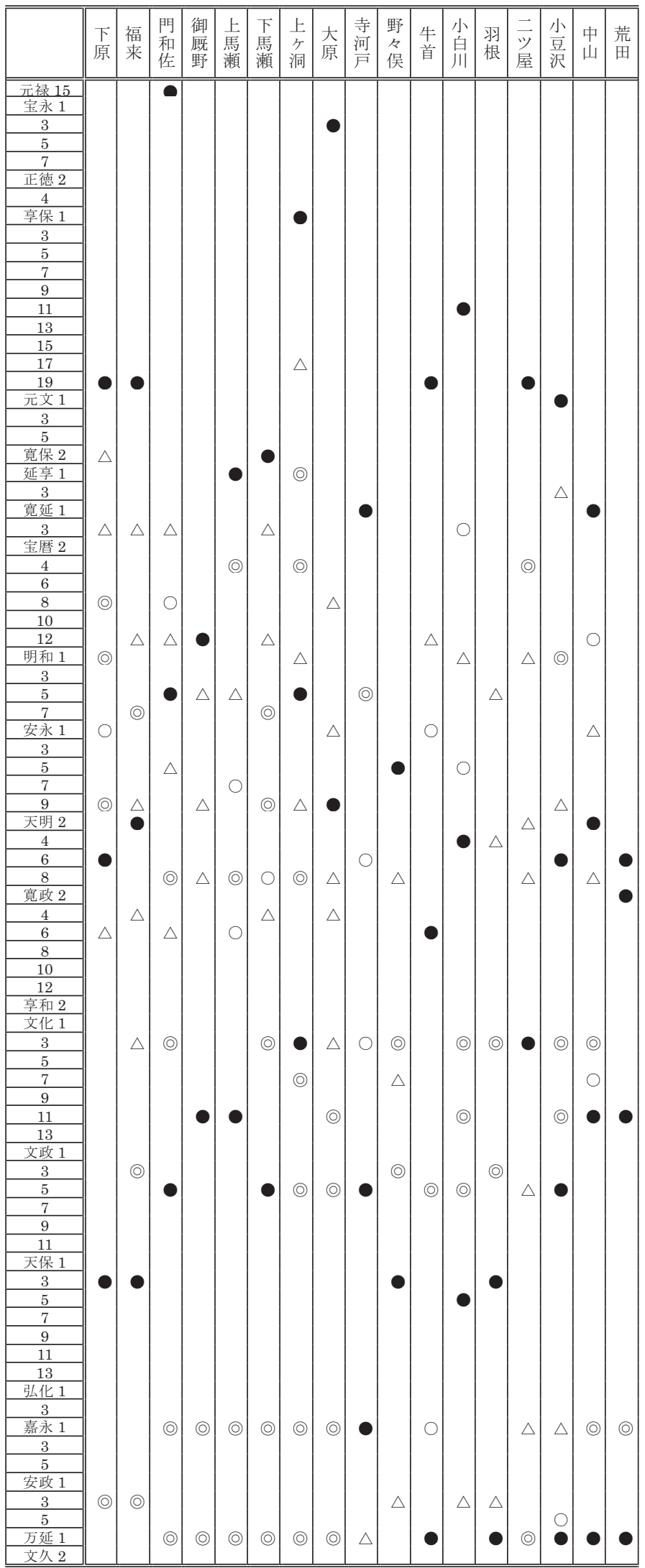

・名称は下原口番所を「下原」というように表記

・○：建替、○：屋根莫替并修復、○：修復、 $\triangle$ : 屋根莫替

・紙面の都合により 2 年単位に区切り表示。

・年代は後世の史料における履歴、又は出来形帳の年代。 
(表紙)

「莫替修覆莫替修覆建替 大原口小白川口小豆沢口

飛州口留番所三ヶ所 御建替・莫替 普請目論見帳

$$
\text { 文政六未年 芝与市右衛門」注20) }
$$

(本文)

「大原口

桁行五間

一 梁間三間

軒高九尺

大野郡
番所屋根莫替并修覆
板原村
此屋

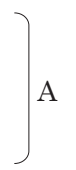

是八、宝永四亥年伊奈半左衛門支配之節御建替、五拾式ヶ 年目宝暦八寅年上倉彦左衛門支配之節屋根莫替、拾五ヶ年 目安永元辰年大原彦四郎支配之節屋根莫替、九ヶ年目九子 年同人支配之節御建替、拾ヶ年目寛政元西年大原亀五郎支 配之節屋根幕替、四ヶ年目同四子年飯塚伊兵衛支配之節屋 根莫替、拾五ヶ年目文化三寅年田口五郎左衛門支配之節屋 根莫替、拾ヶ年目同十二亥年私支配二相成屋根莫替并修覆 被仰付候処、追々破損仕候間是迠分成二取繥置候得共、最 早及大破取繥之手段無御座候間、此度屋根莫替并修覆御普 請被仰付候積目論見左之通二御座候

\section{右御入用}

長式間尺角杣面趈式本四分

尺๙壱本四分四厘

雑木四本 長武間 柱根継木
六寸角
此木拾六本 長三尺

是八壱本を四ツ伐拾六本ニシテ内六本八裏表朽損遣 四本八梁間両側二遣六本八居間并水屋二遣候積リ

（以下省略、「根太木」「大引木」「敷板木」「板留木」 「破風木」「猿頭木」と同様の記載が続く。また文中 の羁線・記号は筆者の加筆による)

ここで記載された建築工事のうち、安永 9 年 (1780) の「建替」、 寛政元年（1789）の「屋根莫替」、寛政 4 年（1792）の「屋根莫替」 については木取仕様帳が残存する。そのほかの残存はみられず、工 事履歴が明記されていても、その工事に関する木取仕様帳が必ず残 存するとは限らない。以下、17 ケ所の番所における木取仕様帳の記 載内容の特徵を検討する。なお残存する史料には百年程度の時期的 な幅があるものの以下で述べる記載形式はほぼ一定していて、時代 的変化はみられない。

\section{2 ）記載内容について \\ (1) 建物の形態}

冒頭（引用文 $\mathrm{A} の$ 箇所）では建物の形態に関する基礎情報が記さ れる。すなわち、建物の種別 (番所、又は木戸門)、間口・奥行・軒 高、屋根材（板莫、荁莫）と屋根坪、工事類型、所在する村名であ る。工事類型は「建替」「修復 (又は修覆)」「屋根莫替」「屋根莫替 并修覆」に分類される。例外的に「普請」(類焼後の再建の場合) や 「引移建替」もみられる。

\section{(2) 工事履歴と建築年齢}

建物の基本的な情報に続いて、工事履歴が示される（引用文 B の 箇所)。この項目が飛騨国における木取仕様帳の重要な特徴といえよ
う。例示した大原口の事例では、113 年前（宝永 4 年）の「建替」 から 5 年前（文化 12 年）の「屋根莫替并修覆」までの約 1 世紀の 間に、 2 回の「建替」、 5 回の「屋根莫替」、 1 回の「屋根莫替并修 覆」を経たとする。また、建替ないし新しく建設された年代が不明 な場合は「年暦不知」と記され、必ずしも全ての木取仕様帳で工事 履歴が網羅されるわけではない。もちろん、ここで明記された工事 履歴以外に「建替」「修復」などが実施されていた可能性も否定でき ない。ただし、残存史料において、別の木取仕様帳と明記された工 事履歴の内容はほぼ符合する。なお、大原口の事例では、例示した 史料から寿命（「建替」から次の「建替」までの建築年齢）が 2 例ほ ど判明する。すなわち、文政 6 年（1823）の普請目論見帳に記載さ れた宝永 4 年（1707）と安永 9 年（1780）の「建替」の記載から宝 永 4 年に建替えられた番所の建築寿命が 73 年と判明する。さらに、 安政 7 年 (1860) の「建替」に関寸る出来形帳から、安永 9 年「建 替」の番所の寿命が 80 年と判明する。このような建築年齢の集積 を後述する。

\section{(3) 工事に至る要因}

工事履歴を列挙した後、申請する当該の工事に至る要因が明記さ れる。例えば、例示した史料では（引用文 B の末尾）「最早及大破 取繕之手段無御座候間」とされる。ほかの史料の記載もあわせて、 工事に至る要因としては、いずれの工事類型においても「破損」「大 破」が大半を占める。そのような経年による物理的劣化(「御建替よ り年暦相立」という文面もみられる）以外に、「雪」「大風」による 劣化の場合もある。また、少数ながら「建替」の要因として、「類焼」 「山崩」「地震」(地震の場合は「建替」と「修復」が共にみられる) といった災害に起因する場合もある。

\section{(4) 木取に関する項目}

次いで、建物の部位ごとに「御林木」(幕府直轄林「御林山」から 杣が新たに伐採した用材）からの製材過程が示される（引用文 C の 箇所）。すなわち例示した史料をみれば、「柱根継木」として用いる 「雑木四本」（2間・6 寸角）に要した杣の仕事、材積（尺ょ注21） で表示)、木挽によって製材された部材数が記される。製材は「伐」 と「挽」が明確に区別される。さらに、部材の建物における配列に 関しても記載される（引用文 D の箇所）。すなわち「御林山」から 伐採した用材から建物に配列されるまでを報告し、その木材量まで が把握できる史料形式である。

\section{(5) 古材の再利用}

部材の製材に関して着目したいのは、「古木」「古板」「古榑」など の古材の再利用に関して明記される点である。例えば、表 3 で例示 した大原口番所の建替普請目論見帳（安政 5 年）をみると、「短木」 「根太木」「掾縁木」「方立木」「垂木」「壁下地木」の項目で、再利 用する部材数が明記された上で「古木用」と書上げられる注22)。ま た「敷板木」では「古板用」、「莫榑代」で「古榑用」、「障子代」で 「古障子用」、「戸代」で「古戸用」といずれも枚数・本数が明記され た上で新材と併記される。

\section{６）木取した用材と既製品}

ほとんどの部位は「御林木」を用いるが、「葺榑」「押木」「木舞」 「鉄物」「壁下地木」「間渡木」「障子」「戸」等の部位に関しては数 量と金額が示され、既製品を購入している注23)。なお「木舞」「壁下 地木」「間渡木」は文政 6 年（1823）の「大原口屋根莫替并修覆」 
では既製品を購入している。それに対して、安永 9 年 (1780) の「建 替御普請出来形帳」では木取して製作していて、時代により相違が ある。購入部材の書上げに続き、「木挽」「大工」「杣」「人足」の賃 金・飯米が記載されて、末尾に賃金・米・用材数（「御林木」「末木」） の合計が記される。

\section{3 ）史料的特徵について}

以上でみた木取仕様帳の特色として、以下の 3 点が挙げられる。 まず、番所普請に関する建築文書が各工程における木材・部材の 書き上げである点である。「御林山」からの伐木数、木取した用材数 と木材量、そしてそれらの建物を組み立てる配列方法という、森林 から建築に至る木材の流れを報告寸る史料である。その主眼は、出 来上がった建物の形態規制ではなく、建築工事で利用した伐木数・ 木材量の合理性の証明 (無駄な伐採を行っていない) と捉えられる。

さらに、古材の再利用が明記される点である。これは、新たな伐 木を抑制しているという幕府勘定所への報告として位置づけられる。 そのことは、「目論見帳」と「出来形帳」において用材数が相違する 場合においても見出すことができる。それらは全て「出来形帳」の 数量の方が、「目論見帳」より少ない (表 2 参照)。実際に工事した 結果の木材量の方が計画より少ないというのは、史料の数量が実際 と一致するか疑問も残るだろう。しかしそれ以上に注目できるのは、 「目論見帳」と「出来形帳」の数量的な相違は、建物の形態の変化 に起因寸るのではなく、古材の再利用が増加したことによる点であ る。「出来形帳」の方が「目論見帳」より古材の再利用数を増加させ た結果、伐木数を減らしたという関係にある注 24$)$ 。古材まで数量的 に報告し、再利用を誘導する木材規制が読み取れよう。

さらに、建築工事が時間軸で管理されている点にも着目できる。 すなわち、「建替」「修復」「屋根莫替」に至った過去の建築年齢を明 記し、その上で当該の工事を申請するという形式がみられる。この ような管理方式は、例えば短寿命での「建替」を抑制する機能を果 たしたことが推察される。その寿命の数的な実態を次に提示する。

\section{3. 建築寿命の分析方法}

以下で、建築寿命の具体的な数值をみていく。まずは、木取仕様 帳から建築年齢と木材量を算出する方法を述べていこう（木材量の 算出事例として表 3 を掲げた)。角材の木材量は長・幅・厚・本数か ら算出するが、丸太の場合は必ず史料に末口の記載があることから 末口自乗法注25)を用いる。これらの計算で、目論見帳と出来形帳の 数值が相違する場合は、出来形帳の数值を用いる。建築年齢を把握 する際に用いる工事の年代は、後世の木取仕様帳に工事履歴として あらわれる年代を優先し（この年代を目論見帳・出来形帳の年代と 照合すると出来形帳と一致する場合がほとんどである)、工事履歴が 記載されない場合（例えば最新の工事の場合）は出来形帳の年代を 用いる。目論見帳と出来形帳の提出年代の差は 2 年程度である（表 2 を参照)。

\section{4. 工事類型ごとの建築年齢と木材量 \\ 1 )「建替」の場合 \\ (1)「建替」に至る建築年齢}

図 3 で建築の寿命が抽出される 31 件の分布を示した。類焼のた
め 5 年で建替えられた荒田口番所が最小值で、最大值は下馬瀬・大 原の 80 年である。災害による突発的な「建替」を除いた平均值は 54 年、 10 年単位の最頻出值は 50 年台（50 年〜 59 年）である。

\section{(2) 木材量からみた「建替」の実態}

図 4 は同一の建物に対寸る「建替」「修復」「屋根莫替」「屋根莫替 并修復」の木材量が比較可能な 6 件の番所をまとめたものである。

「建替」は通常、既存建物を解体した上で新たに建設する行為であ る。ただし、解体によって発生した古材を再利用する場合も報告さ れる。古材の木材量を算出できる事例でみてもその量はわずかであ り、9 割以上は更新される注26)。ただし、類焼後の普請であれば全 ての部材が新材で更新されている。それに対して、地震により生じ た「建替」では、古材の再利用が多くみられ、木材量は類焼普請（全 更新）の 7 割程度である注27)。なお、番所は平面や規模がそれぞれ 異なるため、統一基準として「石／坪」の単位でみれば、「板莫」の 番所の「建替」において使用される木材量は平均で 2.5 石／坪、「萱 莫」の場合は平均で 3.4 石/坪である。この相違は「萱莫」が「板 莫」より小屋組に多くの木材を利用寸ることによる。

表 2 目論見帳と出来形帳の用材が相違する事例

\begin{tabular}{|c|c|c|c|}
\hline $\begin{array}{l}\text { 番所名 } \\
\text { 工事名 } \\
\text { 年代 } \\
\end{array}$ & 目論見帳の用材 & 出来形帳の用材 & $\begin{array}{l}\text { 古材数が増 } \\
\text { 加した部材 }\end{array}$ \\
\hline $\begin{array}{c}\text { 大原 } \\
\text { 修覆并屋根莫替 } \\
\\
\text { 弘化 } 3 \text { 年 } \\
\rightarrow \text { 嘉永元年 }\end{array}$ & $\begin{array}{c}\text { 雑木 } 32 \text { 本 } \\
+ \\
\text { 末木 } 2 \text { 本 } \\
\\
21.13 \text { 石 } \\
\text { (1.41石 / 坪) }\end{array}$ & $\begin{array}{c}\text { 雑木 } 26 \text { 本 } \\
+ \\
\text { 末木 } 2 \text { 本 } \\
19.24 \text { 石 } \\
\text { (1.28 石 } / \text { 坪 })\end{array}$ & $\begin{array}{c}\text { 柱根継木 } \\
\text { 敷板木 } \\
\text { 猿頭木 } \\
\text { 莫榑 }\end{array}$ \\
\hline $\begin{array}{c}\text { 大原 } \\
\text { 建替 } \\
\text { 安政 } 5 \text { 年 } \\
\rightarrow \text { 安政 } 7 \text { 年 }\end{array}$ & $\begin{array}{c}\text { 雑木 } 70 \text { 本 } \\
+ \\
\text { 末木 } 21 \text { 本 } \\
45.64 \text { 石 } \\
\text { (3.04 石/坪) }\end{array}$ & $\begin{array}{c}\text { 雑木 } 64 \text { 本 } \\
+ \\
\text { 末木 } 21 \text { 本 } \\
42.22 \text { 石 } \\
(2.82 \text { 石 } / \text { 坪 })\end{array}$ & $\begin{array}{l}\text { 梁木 } \\
\text { 桁木 } \\
\text { 莫榑 }\end{array}$ \\
\hline $\begin{array}{c}\text { 門和佐 } \\
\text { 屋根莫替并修覆 } \\
\text { 安政 } 5 \text { 年 } \\
\rightarrow \text { 安政 } 7 \text { 年 }\end{array}$ & $\begin{array}{c}\text { 雑木 } 14 \text { 本 } \\
+ \\
\text { 末木 } 3 \text { 本 } \\
15.39 \text { 石 } \\
\text { (0.88 石 / 坪) }\end{array}$ & $\begin{array}{c}\text { 雑木 } 14 \text { 本 } \\
+ \\
\text { 末木 } 3 \text { 本 } \\
\\
13.97 \text { 石 } \\
(0.80 \text { 石 } / \text { 坪 })\end{array}$ & 莫榑 \\
\hline $\begin{array}{c}\text { 寺河戸 } \\
\text { 建替 } \\
\text { 弘化 } 3 \text { 年 } \\
\rightarrow \text { 嘉永元年 }\end{array}$ & $\begin{array}{c}\text { 雑木 } 102 \text { 本 } \\
+ \\
\text { 末木 } 165 \text { 本 } \\
+ \\
\text { 末小小細木 } 4 \text { 束 } \\
\\
52.82 \text { 石 } \\
\text { (3.02 石 / 坪) }\end{array}$ & $\begin{array}{c}\text { 雑木 } 95 \text { 本 } \\
+ \\
\text { 末木 } 165 \text { 本 } \\
+ \\
\text { 末小小細木 } 4 \text { 束 } \\
\\
49.95 \text { 石 } \\
(2.85 \text { 石 } / \text { 坪 })\end{array}$ & $\begin{array}{c}\text { 柱木 } \\
\text { 敷桁木 } \\
\text { 莫萱 }\end{array}$ \\
\hline $\begin{array}{c}\text { 荒田 } \\
\text { 屋根莫替并修覆 } \\
\text { 弘化 } 3 \text { 年 } \\
\rightarrow \text { 嘉永元年 }\end{array}$ & $\begin{array}{c}\text { 雑木 } 124 \text { 本 } \\
+ \\
\text { 末木 } 92 \text { 本 } \\
+ \\
\text { 末小小細木 } 3 \text { 束 } \\
\\
21.78 \text { 石 } \\
\text { (1.45 石 / 坪) }\end{array}$ & $\begin{array}{c}\text { 雑木 } 90 \text { 本 } \\
+ \\
\text { 末木 } 92 \text { 本 } \\
+ \\
\text { 末小小細木 } 3 \text { 束 } \\
\\
20.24 \text { 石 } \\
(1.34 \text { 石 } / \text { 坪 })\end{array}$ & $\begin{array}{c}\text { 柱根継木 } \\
\text { 垂木 }\end{array}$ \\
\hline
\end{tabular}

・史料の年代は「目論見帳の年代 $\rightarrow$ 出来形帳の年代」で表記した。

・「目論見帳の用材」「出来形帳の用材」の項目の上段では元木数（雑木、末 木など）を表示し、木材量（少数第三位を四捨五入。括弧内は坪当たり平 均）を下段に明記した。

・古材数が増加して用材が減少した事例について、その古材再利用の部位を 「古材数が増加した部材」で示した。 


\section{2 )「屋根莫替」「修復」の場合}

(1) 修復に至る建築年齢

「屋根莫替」「修復」「屋根莫替并修復」という工事類型がみられ るが、この使い分けはおよそ次のようなものである。「屋根莫替」は 屋根材（「莫榑」「萱」）を部分的に取り替えることである。この過程 で部分的に小屋組の部材を取り替える場合もある。一方、「修復」は 小屋組だけでなく軸部の部材を取り替えることである。「屋根莫替」 ないし「修復」のみの記載は少なく、ほとんどは「屋根莫替并修復」 である。「屋根莫替」や「修復」は、大風などの災害により突発的に 生じる傾向がみらえる。本稿では「屋根莫替」「修復」「屋根莫替并 修復」をあわせて修復と表記する。前回の工事から修復に至る建築 年齢の平均は「屋根莫替」で 12 年、「修復」も同じく 12 年、「屋根 莫替并修復」は 15 年である。

\section{（2）木材量からみた修復の実態}

「修復并屋根莫替」で使用される木材量は、同一建物の「建替」 の約半分の水準である。また、「板莫」の番所の「屋根莫替」であれ ば、「建替」の 1 割程度の木材量となる。「建替」までの修復の頻度 を表 5 で示した。
(件数)

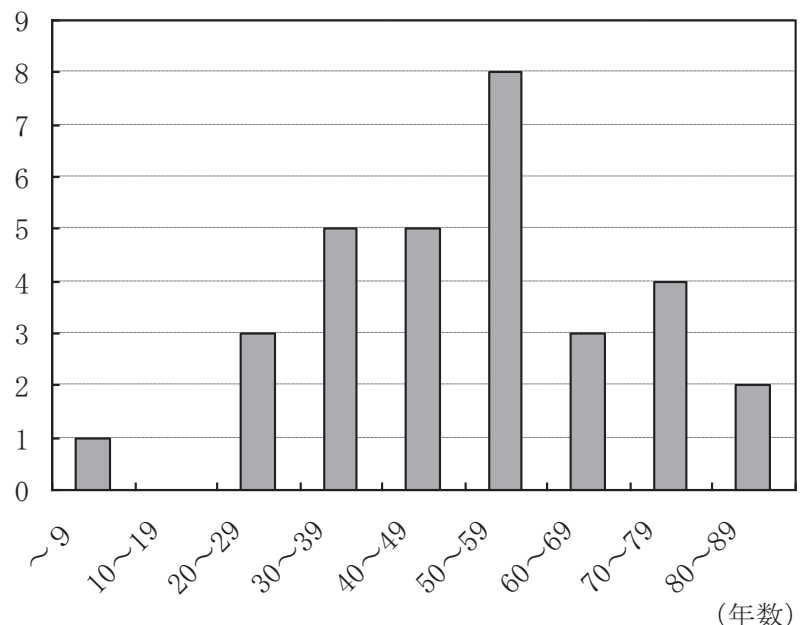

図 3 寿命（「建替」に至る建築年齢）の分布

表 3 木材量の算出例（大原口番所の安政 5 年「建替普請」）

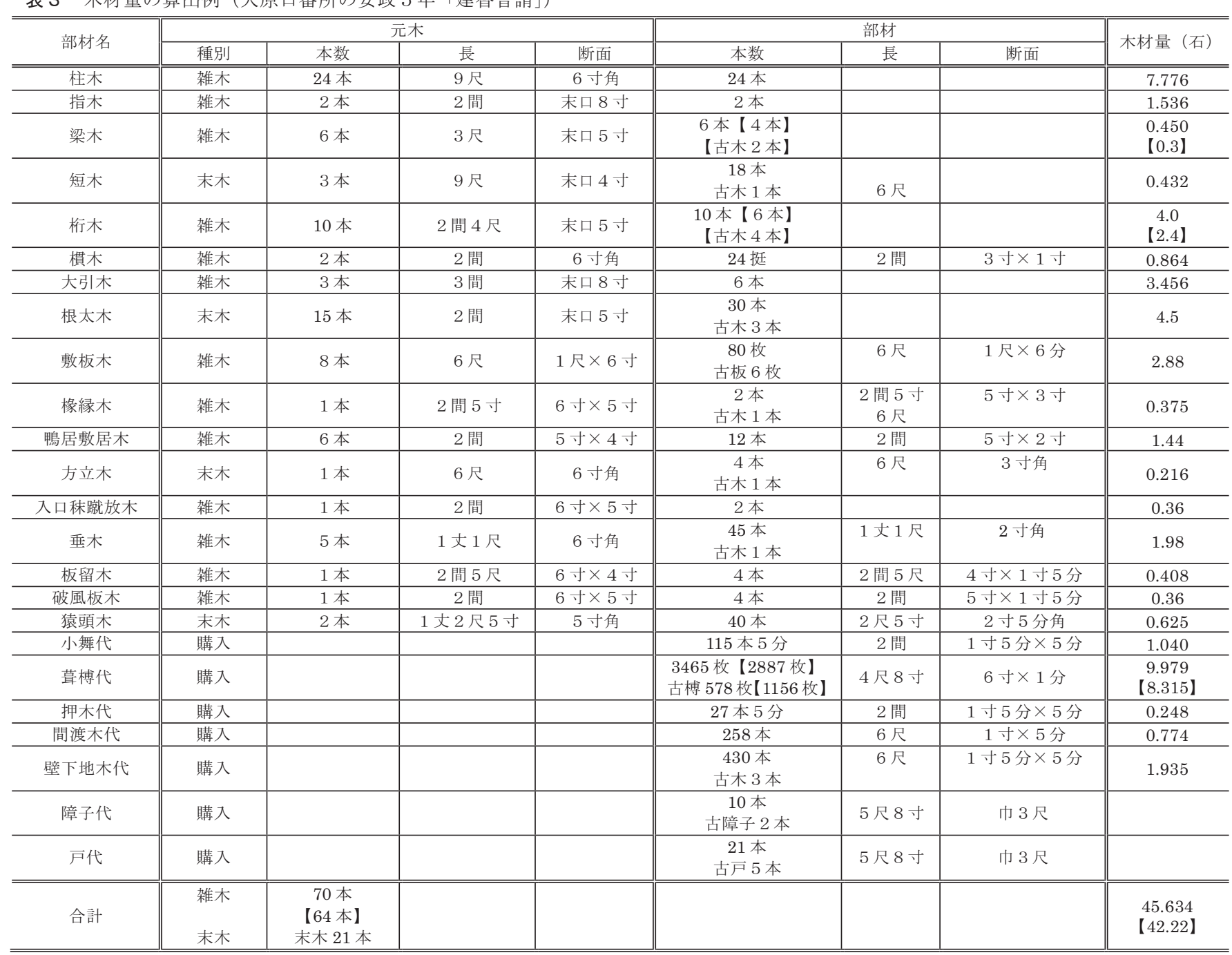

・飛騨郡代高山陣屋文書「飛州口留番所拾三ヶ所・同木戸四ヶ所・御建替・御修覆・草替・御普請目論見帳」目録番号 1-55-114）より作成した。

・史料に記載されている寸法を表示し、目論見帳と出来形帳（安政 7 年）が相違する場合は、出来形帳の数値を【】で併記した。

・「障子」「戸」は木材量の計算からは除外した。 
表 4 番所の寿命 (「建替」に至る建築年齢)

\begin{tabular}{|c|c|c|c|}
\hline 名称 & 第一次 & 第二次 & 第三次 \\
\hline "下原 & ５3 年 & 45 年 & 29 年 $+\alpha$ \\
\hline 福来 & 49 年 & 49 年 & 29 年 $+\alpha$ \\
\hline 門和佐 & 66 年 & 53 年 & 39 年 $+\alpha$ \\
\hline 御厩野 & 53 年 & 46 年 $+\alpha$ & \\
\hline 上馬瀬 & 71 年 & 46 年 $+\alpha$ & \\
\hline 下馬瀬 & 80 年 & 39 年 $+\alpha$ & \\
\hline 上ヶ洞 & 52 年 & 37 年 & 55 年 $+\alpha$ \\
\hline 大原 & 73 年 & 80 年 & 1 年 $+\alpha$ \\
\hline 寺河戸 & 73 年 & 26 年 & 13 年 $+\alpha$ \\
\hline 野々俣 & 56 年 & 29 年 $+\alpha$ & \\
\hline 牛首 & 6 61 年 & 65 年 & 1 年 $+\alpha$ \\
\hline 小白川 & 58 年 & 50 年※ & 26 年 $+\alpha$ \\
\hline 羽根 & 28 年 & 3 年 $+\alpha$ & \\
\hline 二ツ屋 & 72 年 & 55 年 $+\alpha$ & \\
\hline 小豆沢 & 50 年 & 37 年 & 38 年※ \\
\hline 中山 & 34 年 & 33 年 & 45 年 \\
\hline 荒田 & 5 年 & 24 年 & 45 年 \\
\hline
\end{tabular}

・史料で記載される最も古い建替の年代から第一次、第二次とした。

・「※」は目論見帳のみが残存し、その年代を採用したもの

・「」は類焼・大地震・山崩等の災害により突発的に「建替」となったもの。

・参考值として、木取仕様帳の最後の年代である文久元年時点での建築年齢 を示した。建築寿命はその建築年齢以上であり「文久元年での建築年齢十 $\alpha 」$ と表記した（小豆沢・中山・荒田は文久元年の建替のため非表示）。

表 5 「建替」までに修復が行われた回数の例

\begin{tabular}{|c|c|c|c|}
\hline 名称 & 年代 & $\begin{array}{c}\text { 修復回数（周期） } \\
\text { ／寿命 }\end{array}$ & 修復の内訳、回数 \\
\hline 下原 & $\begin{array}{c}1734 \\
\sim 1787\end{array}$ & $\begin{array}{c}6 \text { 回 }(8.8 \text { 年 }) \\
/ 53 \text { 年 }\end{array}$ & $\begin{array}{l}\text { 修復并屋根葺替 } 3 \\
\text { 屋根葺替 } 2 \text { 修復 } 1\end{array}$ \\
\hline 福来 & $\begin{array}{c}1734 \\
\sim 1783\end{array}$ & $\begin{array}{c}4 \text { 回（12.3 年） } \\
/ 49 \text { 年 }\end{array}$ & $\begin{array}{l}\text { 修復并屋根莫替 } 1 \\
\text { 屋根葺替 } 3\end{array}$ \\
\hline \multirow{2}{*}{ 門和佐 } & $\begin{array}{c}1703 \\
\sim 1769\end{array}$ & $\begin{array}{c}3 \text { 回 }(22 \text { 年 }) \\
/ 66 \text { 年 }\end{array}$ & $\begin{array}{l}\text { 屋根莫替 } 2 \\
\text { 修復 } 1\end{array}$ \\
\hline & $\begin{array}{c}1769 \\
\sim 1822 \\
\end{array}$ & $\begin{array}{c}4 \text { 回（13.3 年） } \\
\quad / 53 \text { 年 } \\
\end{array}$ & $\begin{array}{l}\text { 修復并屋根莫替 } 2 \\
\text { 屋根莫替 } 2 \\
\end{array}$ \\
\hline 下馬瀬 & $\begin{array}{c}1742 \\
\sim 1822\end{array}$ & $\begin{array}{c}7 \text { 回 }(11.4 \text { 年 }) \\
/ 80 \text { 年 }\end{array}$ & $\begin{array}{l}\text { 修復并屋根莫替 } 3 \\
\text { 屋根莫替 } 3 \text { 修復 } 1\end{array}$ \\
\hline \multirow{2}{*}{ 上ヶ洞 } & $\begin{array}{c}1717 \\
\sim 1769\end{array}$ & $\begin{array}{c}4 \text { 回（13 年） } \\
\quad / 52 \text { 年 }\end{array}$ & $\begin{array}{l}\text { 修復并屋根葺替 } 2 \\
\text { 屋根葺替 } 2\end{array}$ \\
\hline & $\begin{array}{c}1769 \\
\sim 1806 \\
\end{array}$ & $\begin{array}{c}2 \text { 回 }(18.5 \text { 年 }) \\
\quad / 37 \text { 年 }\end{array}$ & $\begin{array}{l}\text { 修復并屋根莫替 } 1 \\
\text { 屋根葺替 } 1\end{array}$ \\
\hline \multirow{2}{*}{ 大原 } & $\begin{array}{c}1707 \\
\sim 1780\end{array}$ & $\begin{array}{c}2 \text { 回 }(36.5 \text { 年 }) \\
\quad / 73 \text { 年 }\end{array}$ & 屋根莫替 2 \\
\hline & $\begin{array}{c}1780 \\
\sim 1860 \\
\end{array}$ & $\begin{array}{c}6 \text { 回 }(13.3 \text { 年 }) \\
\quad / 80 \text { 年 }\end{array}$ & $\begin{array}{l}\text { 修復并屋根苟替 } 3 \\
\text { 屋根莫替 } 3\end{array}$ \\
\hline 寺河戸 & $\begin{array}{c}1749 \\
\sim 1822\end{array}$ & $\begin{array}{c}3 \text { 回 }(24.3 \text { 年 }) \\
\quad 73 \text { 年 }\end{array}$ & $\begin{array}{l}\text { 修復并屋根莫替 } 1 \\
\text { 修復 } 2\end{array}$ \\
\hline \multirow{2}{*}{ 牛首 } & $\begin{array}{c}1734 \\
\sim 1795\end{array}$ & $\begin{array}{c}2 \text { 回 }(30.5 \text { 年 }) \\
\quad 61 \text { 年 } \\
\end{array}$ & $\begin{array}{l}\text { 屋根莫替 } 1 \\
\text { 修復 } 1\end{array}$ \\
\hline & $\begin{array}{c}1795 \\
\sim 1860\end{array}$ & $\begin{array}{c}2 \text { 回 }(31.5 \text { 年 }) \\
\quad / 65 \text { 年 }\end{array}$ & 修復并屋根莫替 2 \\
\hline \multirow{2}{*}{ 小白川 } & $\begin{array}{c}1727 \\
\sim 1785 \\
\end{array}$ & $\begin{array}{c}4 \text { 回（14.5 年） } \\
\quad / 58 \text { 年 } \\
\end{array}$ & $\begin{array}{l}\text { 屋根莫替 } 2 \\
\text { 修復 } 2 \\
\end{array}$ \\
\hline & $\begin{array}{c}1785 \\
\sim 1835 \\
\end{array}$ & $\begin{array}{c}3 \text { 回 }(16.7 \text { 年 }) \\
\quad / 50 \text { 年 } \\
\end{array}$ & 修復并屋根莫替 3 \\
\hline 二ツ屋 & $\begin{array}{c}1734 \\
\sim 1806 \\
\end{array}$ & $\begin{array}{c}4 \text { 回（18 年） } \\
\quad / 72 \text { 年 } \\
\end{array}$ & $\begin{array}{l}\text { 修復并屋根蕞替 } 1 \\
\text { 屋根莫替 } 3\end{array}$ \\
\hline \multirow{3}{*}{ 小豆沢 } & $\begin{array}{c}1736 \\
\sim 1786 \\
\end{array}$ & $\begin{array}{c}3 \text { 回 }(16.7 \text { 年 }) \\
\quad / 50 \text { 年 } \\
\end{array}$ & $\begin{array}{l}\text { 修復并屋根莫替 } 1 \\
\text { 屋根莫替 } 2 \\
\end{array}$ \\
\hline & $\begin{array}{c}1786 \\
\sim 1823\end{array}$ & $\begin{array}{c}2 \text { 回 }(18.5 \text { 年 }) \\
\quad / 37 \text { 年 }\end{array}$ & 修復并屋根蕞替 2 \\
\hline & $\begin{array}{c}1823 \\
\sim 1862 \\
\end{array}$ & $\begin{array}{c}2 \text { 回 }(19 \text { 年 }) \\
/ 39 \text { 年 } \\
\end{array}$ & $\begin{array}{l}\text { 屋根莫替 } 1 \\
\text { 修復 } 1\end{array}$ \\
\hline \multirow{2}{*}{ 中山 } & $\begin{array}{c}1748 \\
\sim 1782 \\
\end{array}$ & $\begin{array}{c}2 \text { 回（17 年） } \\
\quad / 34 \text { 年 } \\
\end{array}$ & $\begin{array}{l}\text { 屋根莫替 } 1 \\
\text { 修復 } 1 \\
\end{array}$ \\
\hline & $\begin{array}{c}1782 \\
\sim 1815 \\
\end{array}$ & $\begin{array}{c}3 \text { 回（11 年） } \\
\quad / 33 \text { 年 } \\
\end{array}$ & $\begin{array}{l}\text { 修復并屋根莫替 } 1 \\
\text { 屋根葺替 } 1 \text { 修復 } 1 \\
\end{array}$ \\
\hline
\end{tabular}

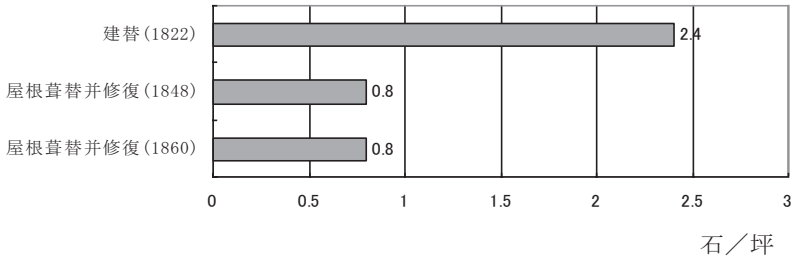

門和佐（板莫）

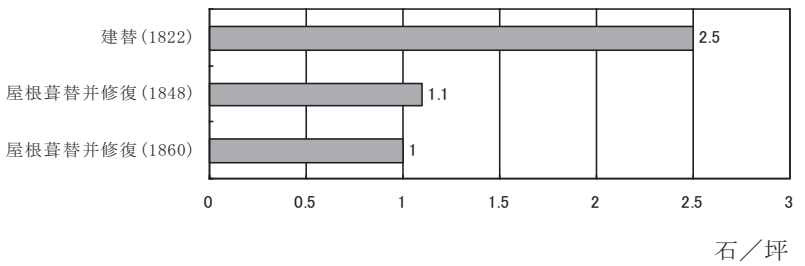

下馬瀬（板莫）
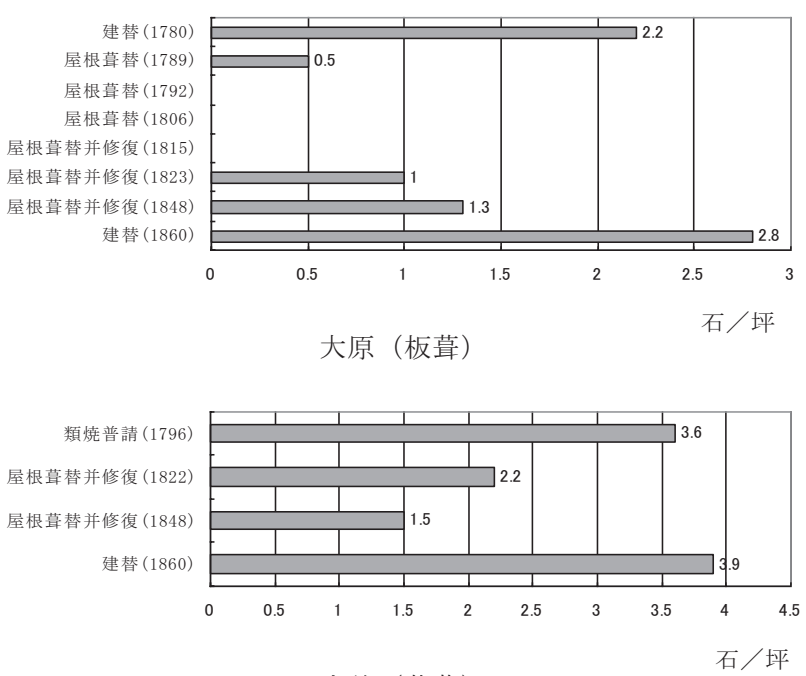

牛首 (萱莫)

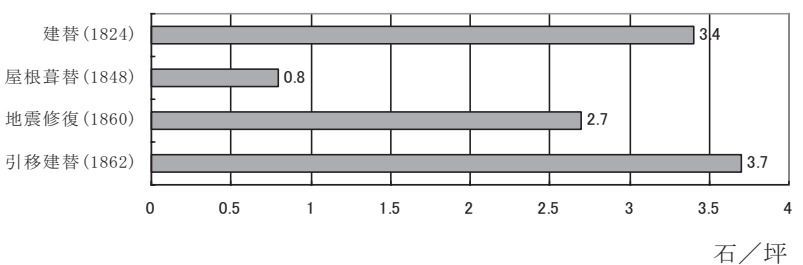

小豆沢（萱莫）

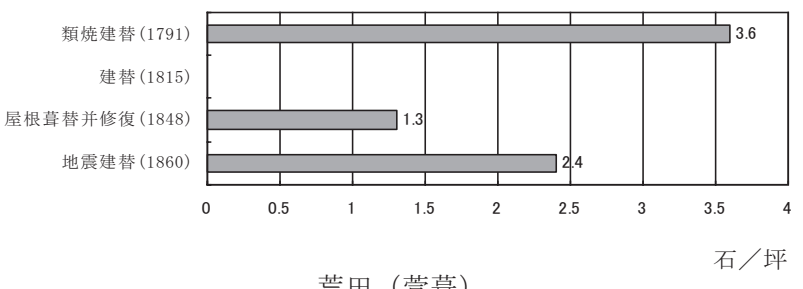

荒田（萱蕞）

図 4 番所の工事類型ごとの木材量（石／坪）

(数值が明示されていないのは木取仕様帳が残存していない工事) 


\section{3 ) ライフサイクルを考慮した木材量について}

図 5 で「建替」から次の「建替」までの同一建物に対する全ての 建築工事の木材量が追跡できる 2 件を示した。同一建物の工事に使 用された木材量の全体のうち、「建替」とその後の修復がおよそ半分 ずつを占める。
〔総量 : 4.0 石 $/$ 坪〕

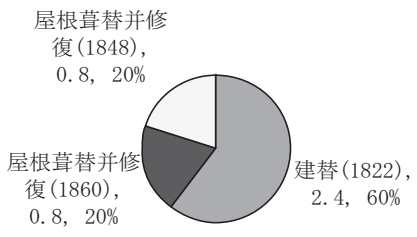

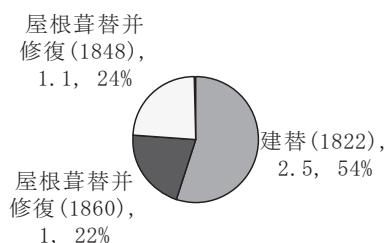

〔総量 : 4.6 石 $/$ 坪

図 5 門和佐（左）と下馬瀬（右）の全木材量（石／坪）

\section{5. 結び}

本稿では幕領・飛騨国の番所普請に関わる木取仕様帳を取り上げ、 伐木数・木材量の列挙、古材再利用の明記、建築年齢の記載という 史料的特徴を指摘した。

さらに、建築年齢の記載という形式から、建築寿命の数值的状況 を以下のように算出した。すなわち、番所の寿命は 24 年から 80 年 の幅を持ち、平均 54 年である注28)。「建替」の木材量は「板葺」の 番所で平均 2.5 石/坪、「萱莫」で平均 3.4 石/坪である。平均 15 年周期に行われる「屋根莫替并修復」の木材量は「建替」の約半分 である。「建替」でも既存建物の古材が再利用されるが木材量で計算 すると少ない。つまり、「建替」により9割以上の部材が更新される。 類焼後の再建においては全て新材で更新される。それに対して、地 震後の「建替」では古材再利用が通常の「建替」より多くみられる。

本研究で検討した 18 世紀から 19 世紀前期の状況を見る限り、時 代が経つにつれて寿命が伸びるような長寿命化の傾向はみられない。 これは史料であらわれる番所が 18 世紀の段階で既に礎石上に立つ ためと推察される注29)。

本稿で提示した寿命の実態は、当時における番所の物理的耐用年 数と捉えられる注30)。同時に、本研究で着眼したのは長期間の工事 履歴の情報管理（当該建物の建築年齢の把握）がなされた上で、当 該の工事を実施するという管理方式の存在でもある。このもとでは、 幾度かの「屋根葺替」や「修復」を繰り返さなければ「建替」が行 なわれないことも推察されよう。長期にわたる工事履歴の把握を高 山陣屋がどのように行っていたのかは未詳である。例えば、保管さ れた過去の木取仕様帳を参照した可能性も考えられる。ただし、建 築年齢が木取仕様帳に記載されるといっても、「建築の長寿命化」そ れ自体が目的ではなかった点には注意したい。むしろ、伐木の抑制 という森林資源の保全策として位置付けられよう。つまり、建築工 事の必要性（建築年齢と工事履歴の記載）ならびに、個々の部材に いたる具体的な用材計画の提示（伐木数、木材量、古材再利用数の 具体的情報を明記）がなければ森林伐採は認められないという、番 所の管理方式が運用されていた。
謝辞：飛騨郡代高山陣屋文書に豊富な建築史料が残存することは筆 者が東京大学大学院在学中に金行信輔先生よりご教示を頂いたもの です。また同史料の閲覧・撮影につきまして岐阜県歴史資料館職員 の皆様にご協力を賜りました。記して感謝申し上げます。

付記：本論文は科学研究費補助金（特別研究員奨励費）による研究 成果の一部である。

\section{注}

注 1 ）各分野を概説した論考集として、農山漁村文化協会編『江戸時代にみ る日本型環境保全の源流』(2002) があり、鬼頭宏『文明としての江戸シ ステム』(2002)、スーザン・ハンレー (指昭博・訳)『江戸時代の遺産』(1990) といった著作も、江戸時代を資源循環型社会とみなす点で共通する。

注 2 ) コンラッド・タットマン（熊崎実・訳）『日本人はどのように森をつく ってきたのか』(1998)、原題は Conrad Totman; The green archipelago ; forestry in preindustrial Japan (1989)。

注 3 ) コンラッド・タットマン前掲書 $\mathrm{pp} 105-107$ 。

注 4 ）徳川宗敬『江戸時代に於ける造林技術の史的研究』（1941）で江戸時 代における森林の「保続」を取り上げるように、この観点は林業史におけ る主要な問題関心である。

注 5 ) 岐阜県歷史資料館所蔵。『飛騨郡代高山陣屋文書目録』(岐阜県歷史資 料保存協会，1983）として目録が公刊されている。また『岐阜県林業史（上 巻・飛騨国編)』、所三男『近世林業史の研究』などの林業史分野で多くの 研究がある。

注 6 ）民家の史料については拙稿「19 世紀中葉の建築語彙にみる民家のライ フサイクル」（日本建築学会大会学術講演梗概集 F 2 、2007）、「家作木願 留にみる飛騨国の農家普請における伐木について」(同、2009) で述べた。

注 7 ) 後述するように今回検討する史料は、高山陣屋から幕府勘定所へと宛 てられたものである。すなわち領主と被支配層（町民、農民、寺社等）と いう関係ではない点に注意したい。

注 8 ) 関野克「家屋の年齢」(『数理科学』151 号、1976)。

注 9 ) 伊藤鄭爾「中世奈良の庶民住宅の耐用年限について」(『日本建築学会 大会学術講演梗概集 (計画系)』1947)。寛正元年 (1460) から同 6 年 (1465) までの地口の間数を分析し、中世庶民住居の耐用年数を平均 20 年と試算。 注 10）伊原惠司「古建築の修理周期」(『普請研究』32 号、1990)。

注 11）草野和夫「所有と改建の状況－石伏村『家別帳』の例」(『近世民家の 成立過程』1995 所収)。会津郡石伏村に伝存する家別帳のうち、享保 3 年 （1718）から天明 5 年（1785）の 5 冊を分析し、中途で上屋規模の記載変 更があった居宅を改築とみて更新状況を試算。それによると「年改築率」 は「約 1 パーセント」で「耐用年数に置き換えると 100 年ほじに当る」「改 築に当たっては同規模に建立することもあったと考えられるから、実態は この数值以上（耐用年数はこれ以下）」とする（p190）。

注 12）宮澤智士「棟札からみた民家の耐用年限（阿波）」(「民家の材料の耐 久性」所収の表、『文化財保存修復研究協議会記録』1985)。棟札が累積し て保存された事例を検討することで、寿命が検討できることを提示した。 具体的な数值はないが「江戸時代にはかなり短い期間で建物を建て替えて いる」（p14）とする。

注 13）生野勇『民家の棟札集成－四国地方の民家を中心として』（1989） 注 14）平山育男「全国の移築民家における移築の行われた時代、移築の理由、 移築の移動距離、移築までの期間とその相互関係」（日本建築学会計画系論 文集 $622 、 2007)$ 。全国の移築民家 161 棟のうち 86 件の移築までの期間を 検討し、平均 79 年とする。

注 15）小松幸夫「建築寿命の推定」『建築雑誌』2002.10。

注 16）代表的な研究として、所三男『近世林業史の研究』(1980)、コンラッ ド・タットマン（熊崎実・訳）『日本人はどのように森をつくってきたのか』 (1998) がある。

注 17）例えば、三宅正久『朝鮮半島の林野荒廃の原因』（1976）では、日本 の江戸時代における民家の木材消費量を「家の大きさ」（15 坪）「家の耐久 年数」(20 年および 30 年)「単位建坪当たり木材使用量」(現在の 3 石の半 分とみて 1.5 石）「家屋数」から試算しているが（p87）、本稿で述べるよう にライフサイクルを考慮すると番所では建設時の 2 倍の木材が必要であり、 上記のような試算は実態に対して極めて少量となる。 
注 18)『高山市史・上巻』（1952） p 714。

注 19)「飛騨郡代高山陣屋文書」目録番号 1-55-115。

注 20）「飛騨郡代高山陣屋文書」目録番号 1-55-105。

注 21）尺メ 1 本の材積は 1 尺× 1 尺× 2 間。

注 22）例えば「雑木 拾五本 長武間・未口五寸 根太木

$$
\begin{aligned}
\text { 此木 三拾本 但壱通挽 } \\
\text { 外 三本 古木用」といった記述がみられる。 }
\end{aligned}
$$

注 23）例えば「飛州口留番所三ヶ所 御建替・莫替 普請目論見帳」（文政 6 年、注 20 参照）の「莫榑」の項目をみれば、

「一、金壱両武分永六拾四文武分 莫榑代

此 莫榑 三千九百六拾枚 但、長四尺五寸 巾四寸・壱分 千枚二付金壱分永百四拾五文

外七百四拾式枚半 古榑用」といった書式をとる。

注 24）大原口番所の「建替」に関する安政 5 年の目論見帳と安政 7 年の出来 形帳（目論見帳に朱書で追筆）の相違で説明しよう（表 2 の上から 2 段目 および表 3 を参照)。目論見帳では「梁木」（長 3 尺・末口 5 寸） 6 本だっ たが、出来形帳では「外、弐本古木用」と追筆されて、新材は 4 本と訂正 された。同じく、目論見帳の「桁木」10 本（長 2 間 4 尺・末口 5 寸）は「外、 四本古木用」とされて出来形帳では 6 本になった。これによって、伐採す る「御林木」（雑木）は 70 本から 64 本に減少した。さらに、目論見帳では 「莫榑代」の項目で、3465 枚の莫博を購入し、「古榑」を578 枚再利用す る予定だった。それが出来形帳では、「古榑」の再利用数を 1156 枚と増加 させて、新しい莫榑の購入は 2887 枚に抑えた。

注 25）末口二乗法と表記されることもある。計算式は「(末口の直径）×（末 口の直径 $) \times$ (長)」である。

注 26）例えば安政 5 年の大原口番所の建替普請の目論見帳（表 3 で例示）を 用いると、 $100 \%$ 更新の木材量は 48.26 石となる。「建替」の木材量 45.63 石はその約 $95 \%$ に相当する。

注 27）図 4 で「類焼普請」と「地震建替」が比較できるのは小豆沢口番所や 荒田口番所である。

注 28）これらの数值実態は、現存する歷史的建造物とは異なるライフサイク ルのあり方である。すなわち、現存する歴史的建造物が長寿命であるのは、 ある時点で耐久性を獲得した建築が生き残っているのであり、それが過去 における歴史的な実態ではないことを改めて確認しておきたい。

注 29 ) 安永 9 年の「大野郡大原口御番所普請出来形帳」(岐阜県歴史資料館 「飛騨郡代高山陣屋文書」目録番号 1-55-90、『岐阜県史・史料編・近世七』 所収）の「柱木」の項に「但、石居」とある。
注 30）前述のように番所と建築的特徽が類似するのは、農家である。建築寿 命が 50 年程度という水準は草野和夫氏による農家の寿命を 100 年以下と する推定 (注 11 参照)、平山育男氏による移築されるまでの期間が平均 79 年とする報告（注 14 参照）とも矛盾しないからである。平山氏が検討した のは現在まで生き残った上層の農家と考えられるから、過去のある時点に おける実態に対して、長寿命の集団を検討していることが推察される。

\section{参考文献}

1 ）農山漁村文化協会（編）：江戸時代にみる日本型環境保全の源流，農山漁 村文化協会, 2002

2 ）鬼頭宏：文明としての江戸システム，講談社，2002

3 ）スーザン・ハンレー（指昭博・訳）：江戸時代の遺産，中央公論社，1990

4 ）コンラッド・タットマン（熊崎実・訳）：日本人はどのように森をつくっ てきたのか，築地書館， 1998

5 ）徳川宗敬：江戸時代に於ける造林技術の史的研究，西ヶ原刊行会，1941

6 ）岐阜県歴史資料館（編）：飛騨郡代高山陣屋文書目録，岐阜県歴史資料保 存協会, 1983

7 ）岐阜県（編）：岐阜県林業史（上巻・飛騨国編），岐阜県，1984

8 ) 所三男：近世林業史の研究，吉川弘文館，1980

9 ) 中村环巳：19 世紀中葉の建築語彙にみる民家のライフサイクル，日本建 築学会大会学術講演梗概集 F 2, pp 109-110, 2007.7

10) 中村玩巳:「家作木願留」にみる飛騨国の農家普請における伐木について, 日本建築学会大会学術講演梗概集 F 2, pp543-544, 2009.8

11）関野克：家屋の年齢，数理科学 151 号, pp67-72, 1976.1

12）伊藤鄭爾：中世奈良の庶民住宅の耐用年限について，日本建築学会大会 学術講演梗概集 (計画系), pp9-10, 1947.11

13）伊原惠司：古建築の修理周期，普請研究 32 号， 1990

14）草野和夫：近世民家の成立過程，中央公論出版会，1995

15）宮澤智士：民家の材料の耐久性，文化財保存修復研究協議会記録，1985

16）生野勇：民家の棟札集成一四国地方の民家を中心として，文化財建造物 保存技術協会, 1989

17）平山育男：全国の移築民家における移築の行われた時代、移築の理由、 移築の移動距離、移築までの期間とその相互関係，日本建築学会計画系論 文集 622, pp187-192，2007.12

18）小松幸夫 : 建築寿命の推定, 建築雑誌, pp28-29, 2002.10

19）三宅正久：朝鮮半島の林野荒廃の原因, 農林出版, 1976

20）高山市（編），高山市史・上巻，高山市， 1952 